\title{
PŘEHLED AKTUÁLNÍ JUDIKATURY II/2017
}

\author{
DOMINIKA GALAJDOVÁ, FRANTIŠEK KASL, PAVEL LOUTOCKÝ, \\ JAKUB MÍŠEK, HELENA PULLMANNOVÁ, ANNA ŠTEFANIDESOVÁ, \\ JAN ZIBNER
}

\section{ČEZ NENÍ POVINNÝM SUBJEKTEM PODLE ZÁKONA O SVOBODNÉM PŘÍSTUPU K INFORMACÍM \\ Soud: $\quad$ Ústavní soud České republiky \\ Věc: $\quad$ IV. ÚS $1146 / 16$ \\ Datum: 20.6. 2017 \\ Dostupnost: nalus.usoud.cz}

Spolek V havarijní zóně JE Temelín, z.s. (dále jen „Spolek“) požádal obchodní společnost $\check{C} E Z$, a.s. (dále jen „Společnost“) v roce 2006 o poskytnutí informací o jaderném palivu používaném v elektrárně Temelín. Společnost ale rozhodla o neposkytnutí informací s odkazem na ochranu obchodního tajemství. Proti uvedenému podal Spolek odvolání s oporou v zákoně č. 106/1999 Sb., o svobodném přístupu k informacím (dále jen „ZSPI“), o kterém Společnost odmítla rozhodnout. Tento postup byl shledán správným krajským soudem $s$ argumentem, že Společnost není povinným subjektem dle ZSPI. Uvedený názor však byl úspěšně zrušen rozhodnutím Nejvyššího správního soudu (dále jen „NSS“) v r. 2016. ${ }^{1}$

Proti rozhodnutí NSS podala Společnost ústavní stížnost pro porušení svých základních práv, a to práva na rovné zacházení, ochranu vlastnické-

\footnotetext{
1 Tomuto rozhodnutí předcházelo několik rozsudků $\mathrm{v}$ rámci soustavy správních soudů $\mathrm{v}$ období od r. 2006 do r. 2015. Přehledná procesní historie se nachází v detailní anotaci na s. 123-135.
} 
ho práva, soukromí a soudní ochranu, jak jsou uvedena $\mathrm{v}$ zákoně č. 23/1991 Sb., kterým se uvozuje Listina základních práv a svobod (dále jen „Listina“) v čl. 1, čl. 3 odst. 1, čl. 11 odst. 1 , čl. 7 odst. 1, čl. 10 odst. 3 a čl. 36 odst. 1 .

Ústavní soud se tak zaobíral otázkou, zda podřazením Společnosti pod § 2 odst. 1 ZSPI došlo k ústavně nekonformnímu výkladu pojmu „veřejné instituce“, a tudíž k porušení základních práv Společnosti.

Zmíněná povinnost k poskytnutí informací musí být stanovena zákonem a nesmí odporovat principům demokratického právního státu, vč. požadavku na jasnost, určitost, předvídatelnost, srozumitelnost a vnitřní bezrozpornost zákona. ${ }^{2}$ „Pro jednotlivce musí být při použití obvyklých metod výkladu právních norem [tato povinnost] seznatelná ze znění zákona “3 a musí šetřit podstaty a smyslu jeho ostatních základních práv a svobod. ${ }^{4}$ Ve vztahu k soukromoprávním subjektům tak nelze a nesmí být výkladem dovozována žádná dodatečná kritéria pro jejich podřazení pod § 2 odst. 1 ZSPI. ${ }^{5}$

Ani názor NSS, že Společnost je povinným subjektem podle ZSPI, protože je fakticky ovládaná státem prostřednictvím vlastnického práva $\mathrm{k}$ většinovému podílu ve Společnosti, Ústavní soud nesdílí. „Stát totiž bez ohledu na velikost svého podílu v obchodní společnosti pouze vykonává svá práva, jež mu jako jakémukoliv jinému akcionáři přiznávají předpisy práva soukromého. “6 Při akceptování závěrů NSS by tak soukromoprávní společnost byla odkázána v otázce určení svých povinností až na ex post posouzení věci soudem. ${ }^{7}$

S ohledem na výše uvedené Ústavní soud předcházející rozhodnutí správních soudů zrušil pro porušení práva vlastnit majetek a práva podnikat nebo vykonávat jinou hospodářskou činnost Společnosti, jak uvádí čl. 11 odst. 1 a čl. 26 odst. 1 Listiny.

\footnotetext{
Bod 53 anotovaného nálezu.

3 Tamtéž.

4 Tamtéž.

5 Bod 67 anotovaného nálezu.

6 Bod 77 anotovaného nálezu.

7 Tamtéž.
} 


\section{SLEDOVÁNÍ ZAMĚSTNANCŮ PŘI VÝKONU PRÁCE POMOCÍ GPS}

Soud:

Městský soud v Praze

Věc:

6 A $42 / 2013-48$

Datum:

5. 5.2017

Dostupnost:

nssoud.cz

Česká pošta (dále jen „ČP“) provozovala po dobu jednoho roku off-line sledování práce všech poštovních doručovatelů za pomoci GPS trackerů. Zaznamenávané údaje se neomezovaly na čas a místo navštívení doručovacího místa, ale sledovaly celou trasu pochůzek. Identita doručovatele byla zjistitelná z oddělené databáze rozpisu služeb, ačkoli propojení databází nebylo prokázáno. ČP za této situace nepovažovala záznamy za zpracování osobních údajů ve smyslu zákona o ochraně osobních údajů a neopatřovala tedy souhlas zaměstnanců se zpracováním.

Úřad pro ochranu osobních údajů (dále jen „ÚOOÚ“) shledal tento postup za zpracování osobních údajů a za sledování zaměstnanců v rozporu s právem na ochranu jejich soukromí na pracovišti a při absenci zákonného podkladu jej označil za neoprávněný. $V$ rámci následného řízení o námitkách proti kontrolnímu protokolu uložil ČP, aby zlikvidovala dosud zpracovávané údaje vyjma údajů o příchodu na doručovací místo a aby nezpracovávala údaje kontinuálně každý pracovní den vyjma údajů o místě a času navštívených doručovacích míst. ČP se proti rozhodnutí bránila žalobou k Městskému soudu v Praze na přezkum těchto výroků.

Soud se v odůvodnění rozsudku z velké části ztotožnil se závěry ÚOOÚ. Za nedůvodnou označil námitku, že smyslem sledování bylo získání statistických údajů pro zvýšení efektivity procesů, nikoliv sledování zaměstnanců. Ve věci shledal dlouhodobé systematické shromažd’ování osobních údajů. Na zpracování aplikoval test proporcionality, přičemž poměřoval právo na ochranu soukromí zaměstnance s povinností zabezpečit řádné doručení zásilek a listovní a poštovní tajemství dle poštovního zákona. Ohledně vhodnosti soud konstatoval, že postup nebyl zpo̊sobilý eliminovat případné lidské selhání doručovatele. Co do potřebnosti bylo dovo- 
zeno, že plnit povinnost dle poštovního zákona šlo zajistit i bez této míry zpracování osobních údajů zaměstnanců, tedy bez jejich nepřetržitého monitorování. Vzhledem ke kritériu proporcionality se pak jedná o nepřiměřený zásah do soukromí, jelikož o zaměstnanci je během výkonu práce zaznamenáván každý pohyb, což nelze mít za přiměřené se sledovaným účelem. Soud tak neshledal pochybení na straně ÚOOÚ a potvrdil uložené opatření k nápravě, které omezilo rozsah užití GPS trackerů.

Rozhodnutí nabízí potvrzení mantinelů pro monitorování zaměstnance dané právem garantovanou mírou ochrany jeho osobních údajů a soukromí. $\mathrm{Z}$ rozhodnutí ovšem také nepřímo vyplývá, že míra původního zásahu do soukromí zaměstnanců by byla př́ípustná na základě jejich souhlasu.

\section{OMLUVA PROSTŘEDNICTVÍM WEBOVÉ STRÁNKY}

Soud: $\quad$ Nejvyšší soud

Věc: $\quad 20$ Cdo $1741 / 2017$

Datum: $\quad$ 1.6.2017

Dostupnost: nsoud.cz

Jihočeská univerzita v Českých Budějovicích (dále jen „Povinná“) bezdůvodně zadržovala hotová a rozpracovaná díla doc. RNDr. J. K., CSc. (dále jen „Oprávněný“) po dobu 1,5 roku, za což oprávněný požadoval omluvu na webových stránkách Povinné.

Na základě vykonatelného rozsudku Krajského soudu v Českých Budějovicích ve spojení s rozsudkem Vrchního soudu v Praze měla Povinná zveřejnit omluvu ve lhůtě tří dnů od právní moci rozsudku. Povinná tak učinila, nicméně podle Oprávněného nebyla zveřejněná omluva dostatečná, protože neobsahovala elektronický podpis. Okresní soud usnesením rozhodl, že Povinná má zaplatit pokutu 10.000,- Kč pro nesplnění povinnosti uložené soudem. Povinná se odvolala a Krajský soud v Českých Budějovicích dospěl k závěru, že Povinná splnila omluvu řádně a pokud Oprávněný v novém sporu požaduje, aby Povinná uveřejnila omluvu s elektronickým podpisem, není to $\mathrm{v}$ souladu s exekučním titulem, nebơ ten povinnost elek- 
tronického podpisu neuložil. Oprávněný napadl usnesení odvolacího soudu dovoláním.

Dovolací soud se zabýval otázkou, zdali je u omluvy zveřejněné na webové stránce třeba postupovat dle příslušných ustanovení v občanském zákoníku ohledně písemné formy ${ }^{8}$ a nutnosti podpisu při elektronickém právním jednání ${ }^{9}$ nebo má přednost exekuční titul (který vychází ze žalobního petitu).

Nejvyšší soud již dřive judikoval, že splnění povinnosti otisknout omluvu lze dostát pouze při dodržení konkrétní formy, obsahu a rozsahu omluvy vymezených ve výroku př́slušného rozhodnutí (exekučního titulu). ${ }^{10} \mathrm{~V}$ rozhodnutí týkajícím se podmínek pro omluvu otištěnou v periodickém tisku pak došel k závěru, že stačí naplnění dvou kumulativních podmínek: za prvé musí odpovídat svému vymezení v exekučním titulu a za druhé nesmí z jejího kontextu vyplývat, že není míněna vážně. ${ }^{11}$ Dle Nejvyššího soudu byla obě rozhodnutí aplikovatelná na tento případ.

Nejvyšší soud rozhodl, že omluva byla zveřejněna řádně $s$ ohledem na dřívější judikaturu a také proto, že exekuční titul nestanovil povinnost elektronického podpisu, a nestanovil tím proto ani povinnost písemné formy omluvy.

\footnotetext{
8 § 561 odst. 1 zákona č. 89/2012 Sb.

$9 \S 562$ odst. 1 zákona č. 89/2012 Sb.

10 Usnesení NS ČR, sp. zn. 20 Cdo 3272/2006.

11 Usnesení NS ČR, sp. zn. 20 Cdo 3729/2016.
} 


\section{THE PIRATE BAY JAKO SDĚLOVÁNÍ VEŘEJNOSTI ${ }^{12}$}

Soud:

Soudní dvůr Evropské unie

Věc: C-610/15 (Stichting Brein proti Ziggo BV, XS4ALL Internet $\mathrm{BV})$

Datum: 14. 6. 2017

Dostupnost: curia.europa.eu

Společnosti Ziggo BV a XS4ALL Internet BV poskytovaly přístup k internetu. Většina jejich klientů využívala online platformu pro sdílení The Pirate Bay umožňující stahování souborů BitTorrent, tedy mimo centralizovaný server z počítačů jednotlivých uživatelů. Nadace Stichting Brein zastupující nositele autorských práv se domáhala vůči společnostem blokace doménových jmen a IP adres The Pirate Bay kvůli rozsáhlému porušování autorských práv.

Soud v prvním stupni návrhům Stichting Brein vyhověl, avšak odvolací soud rozhodnutí zrušil a návrhy nadace zamítnul. Po dovolání Nejvyšší soud Nizozemska poukázal na specifičnost platformy a nemožnost rozhodnout v kontextu nejistého výkladu institutu sdělování veřejnosti.

Soudní dvůr Evropské unie (dále jen „Soudní dvůr") musel rozhodnout, zda se jedná o sdělování veřejnosti provozovatelem internetové stránky, jestliže neobsahuje chráněná díla, avšak poskytuje služby, které umožňují využívat existující systém pro indexaci a kategorizaci metainformací o chráněných dílech, jež se nacházejí v zařízeních uživatelů, aby tito následně dokázali nacházet, nahrávat a stahovat chráněná díla.

Rozhodnutí se týkalo zejména výkladu sdělování díla veřejnosti ve smyslu čl. 3 směrnice Evropského parlamentu a Rady 2001/29/ES ze dne 22. května 2001 o harmonizaci určitých aspektů autorského práva a práv s ním souvisejících v informační společnosti (dále jen „směrnice InfoSoc“).

\footnotetext{
12 Detailní anotace rozhodnutí se nachází na s. 149-159.
} 
Soudní dvůr přitom hojně odkazoval na své předchozí rozhodnutí C-527/15 ${ }^{13}$ uvádějící předchozí judikaturu v otázce sdělování veřejnosti.

Po vysvětlení problematiky torrent, shrnutí základních aspektů sdělování veřejnosti a vyzdvižení podstaty ochrany autorských děl Soudní dvůr zdůraznil nepominutelnou úlohu uživatele, vědomou povahu zásahu, jakož i blíže neurčený počet potenciálních adresátů, to vše v kontextu nové veřejnosti. Soudní dvưr dále vytvořil paralelu mezi uživateli a provozovateli platformy, která nelegální zpřístupňování děl skrze aktivní prvky jako rejstřík a indexace ulehčuje, čímž hraje nepominutelnou úlohu.

Soudní dvưr na základě toho rozhodl, že sdělování veřejnosti dle směrnice InfoSoc zahrnuje zpřístupnění a správu platformy pro sdílení obsahu na internetu umožňující uživatelům díla nacházet a sdílet v rámci sítě peer-to-peer skrze indexaci metadat jednotlivých děl a vyhledávač pro tato metadata.

\section{OCHRANA NESPECIFICKÝCH DAT PRÁVY SUI GENERIS}

Soud: $\quad$ Court of Appeal of England a Wales (odvolací soud pro Anglii a Wales)

Věc: $\quad$ HC-2016-000257

Datum: 24. 8. 2017

Dostupné: bailii.org

V rámci vývoje ECG Cloudu vytvořily společnosti Technomed Limited a Technomed Telemedicine Limited (dále jen společně jako „Technomed“) databázi, která obsahovala soustavu klasifikací tělesných vlastností zjištěných pomocí EKG společně se seznamem možností nejvhodnější léčby (dále jen „Databáze“). ECG Cloud v rámci screeningu vytvořil dokument se standardním XML formátem, kdy informace $\mathrm{z}$ tohoto dokumentu byly následně vloženy do standardizované zprávy o stavu pacienta, která rovněž

13 Rozsudek Soudního dvora (druhého senátu) ze dne 26. dubna 2017. Věc C-527/15. Stichting Brein v. Jack Frederik Wullems (Filmspeler). In: EUR-Lex [právní informační systém]. Úřad pro publikace Evropské unie [cit. 17. 12. 2017]. Dostupné z: http://eur-lex.europa.eu/legal-content/EN/TXT/?uri = CELEX\%3A62015CJ0527 
zahrnovala diagramy a vysvětlivky. Technomed uzavřel se společností Bluecrest Health Screening Limited (dále „Bluecrest“) smlouvu o poskytování služeb ECG Cloudu, přičemž jí také zpřístupnil Databázi ve formě PDF dokumentu a další materiály. V době trvání smluvního vztahu se Bluecrest obrátil na Express Diagnostic Limited (dále „Express“) se zájmem o poskytování služeb screeningu. V této době Bluecrest zaslal Express také emaily obsahující XML dokument, kopii Databáze ve formátu PDF, vysvětlivky atd. Následně společnost Bluecrest ukončila smluvní vztah se společností Technomed, kdy tato byla nahrazena společností Express.

Odvolací soud pro Anglii a Wales se ve svém rozhodnutí řešil mimo jiné otázku porušení práv sui generis Technomed k Databázi (PDF) a porušení autorských práv k XML dokumentu. Soud se zabýval výkladem ustanovení článku 1 odst. 2 směrnice o ochraně databázi ${ }^{14}$ a jeho aplikací a dále povahou XML dat jakožto díla. $\mathrm{V}$ této věci soud také vycházel ze svého předchozího rozhodnutí Football Dataco ${ }^{15}$, kdy byl tento spor projednáván i v rámci řízení o předběžné otázce před SDEU. ${ }^{16}$

Soud rozhodl, že PDF dokument obsahující Databázi je chráněn právy sui generis $\mathrm{k}$ této databázi, nebot se jedná o souhrn prvků, $\mathrm{k}$ jejichž obdržení, třídění a verifikaci bylo nezbytné vynaložit nezanedbatelné náklady ze strany Technomed. Soustavné vytěžování a opětovné používání nepodstatných části Databáze z tohoto dokumentu je porušením práv sui generis autora $\mathrm{k}$ databázi. Soud se dále vyjádřil k porušení autorských práv $\mathrm{k}$ XML dokumentu. Soud uzavřel, že programovací jazyk XML nepodléhá ochraně jakožto software. To ovšem nevylučuje ochranu dokumentu, vytvořeného $\mathrm{v}$ tomto programovacím jazyku, jakožto literárního díla. Soud v tomto případě stanovil, že s ohledem na vlastnosti programovacího jazyka, kdy je

\footnotetext{
${ }^{14}$ Směrnice Evropského parlamentu a Rady 96/9/ES ze dne 11. března 1996 o právní ochraně databází.

15 Rozhodnutí odvolacího soudu pro Anglii a Wales ze dne 6. února 2013, ve věci Football Dataco Limited v Sportradar GmbH, sp. zn. (2013) EWCA Civ 27. Dostupné z www.bailii.org

16 Rozsudek ze dne 18. ř́ijna 2012, Football Dataco Ltd and Others v Sportradar GmbH and Sportradar AG, C-173/11, EU:C:2012:642.
} 
možné jednotlivé programy vytvářet kreativně, lze vyjádření v tomto jazyce považovat za originální výtvor autora.

Soud rozhodl, že ze strany Bluecrest a Express došlo k porušení práv sui generis k Databázi a autorských práv k XML dokumentu společnosti Technomed.

\section{OBRAT PŘI POSUZOVÁNÍ ZÁSAHU DO SOUKROMÍ PŘI SLEDOVÁNÍ AKTIVITY ZAMĚSTNANCE NA INTERNETU ZAMĚSTNAVATELEM}

Soud: $\quad$ Evropský soud pro lidská práva - Velký senát

Věc: $\quad$ Bărbulescu proti Rumunsku, č. 61496/08

Datum: $\quad$ 5. 9. 2017

Dostupnost: hudoc.echr.coe.int

ESLP se v této věci opětovně zabýval otázkou monitorování zaměstnance zaměstnavatelem (poprvé 12. 1. 2016). K danému se nyní vyjádřil Velký senát ESLP.

Pan Bărbulescu (dále jen „Stěžovatel“) byl zaměstnán v soukromé společnosti a dle pokynu svého zaměstnavatele si zř́́dil účet na Yahoo Messenger, aby mohl odpovídat na dotazy klientů. Stěžovatel byl svým zaměstnavatelem posléze informován, že jeho komunikace byla monitorována. Zaměstnavatel shledal, že Stěžovatel v rozporu s interními pravidly využíval internet v pracovní době k soukromým účelům. To stěžovatel popíral, zaměstnavatel však kontroval přepisem jeho komunikace, která se týkala mj. zdravotního stavu stěžovatele a jeho sexuálního života. $\mathrm{Z}$ důvodu porušení interních předpisů byl stěžovateli ukončen pracovní poměr.

Stěžovatel se postupně bránil u národních soudů a když neuspěl, případ dospěl až k ESLP. Ten ve svém původním rozhodnutí z 12. 1. 2016 sice potvrdil, že k zásahu do soukromí objektivně došlo (zaměstnavatel měl přístup $\mathrm{k}$ soukromým zprávám), nicméně posuzoval především, jestli rumunské soudy přistupovaly $\mathrm{k}$ rozhodnutí o zásahu do soukromí Stěžovatele proporcionálně vzhledem k oprávněným zájmům zaměstnavatele. 
ESLP tak původně dovodil, že se jednalo o přiměřený a dostatečně omezený zásah do soukromí stěžovatele a $\mathrm{k}$ porušení čl. 8 Evropské úmluvy o ochraně lidských práv upravujícího právo na respektování soukromého a rodinného života (dále jen „Úmluva“) nedošlo.

$S$ tím se však Stěžovatel neztotožnil a věc byla postoupena $k$ rozhodnutí Velkému senátu ESLP.

Soud nejprve v souladu se svou předchozí rozhodovací praxí potvrdil, že jednotlivci mají právo na soukromí na pracovišti, a zásahy do soukromí tak musí být důvodné a proporcionální. $\mathrm{V}$ návaznosti na to pak (oproti předchozímu rozhodnutí) konstatoval, že stěžovatel nebyl předem dostatečně informován o tom, že jeho komunikace bude monitorována (tato skutečnost nebyla uvedena $\mathrm{v}$ interních předpisech zaměstnavatele a nebyla ani nijak jinak zaměstnanci sdělena). Rovněž konstatoval, že rumunské soudy dostatečně nechránily právo na soukromí a zdůraznil, že je nutno posuzovat zejména (i) rozsah monitorování (zaměstnavatel monitoroval $\mathrm{v}$ daném časovém období veškerou komunikaci), (ii) legitimní důvod zaměstnavatele pro sledování, (iii) proporcionalitu zvolených nástrojů. Velký senát ESLP tedy předchozí rozhodnutí senátu změnil a konstatoval, že k porušení čl. 8 Úmluvy došlo.

Z rozhodnutí je ovšem patrná jistá rozpolcenost a argumentace vztahující se $\mathrm{k}$ souhlasu zaměstnance $\mathrm{s}$ monitorováním je problematická. Úroveň míry zásahu při monitorování byla shledána za hraniční, jelikož nebylo národními soudy dostatečně posouzeno, zda mohla být komunikace přístupná i bez vědomí (a souhlasu) zaměstnance, či nikoli. Na druhou stranu je faktem, že byla sice zaznamenávána veškerá komunikace, ale jinak k prokázání tvrzeného nemohlo dojít a monitoring byl jen dočasný (v rozsahu 9 dní). Navíc stěžovatel daný komunikační nástroj využíval na základě pokynu zaměstnavatele. 


\section{ÚSTAVNÍ TEČKA ZA PŘÍPADEM EKOLO.CZ}
Soud:
Ústavní soud
Věc:
III. ÚS 3565/16
Datum:
5. 9.2017
Dostupnost:
nalus.usoud.cz

Společnost ekolo.cz (dále „Stěžovatelka“) zveřejnila na svých webových stránkách a profilu na síti Facebook fotografii muže podezřelého z krádeže elektrokola $s$ výzvou $\mathrm{k}$ dalšímu sdílení za účelem objevení pachatele. Po zveřejnění fotografie Stěžovatelka rovněž oznámila odcizení kola policii. Za neoprávněné zpracování osobních údajů v rozporu s účelem, ke kterému byly shromážděny, jejich sdílením a rozšiřováním a nesplnění registrační povinnosti, uložil Úřad pro ochranu osobních údajů (dále „ÚOOÚ“) Stěžovatelce pokutu.

Stěžovatelka podala rozklad, ten byl však zamítnut předsedou ÚOOÚ. Městský soud v Praze po žalobě Stěžovatelky rozhodnutí ÚOOÚ zrušil. Odůvodnil to zejména tím, že nedošlo ke zpracování za jiným účelem - ten byl dle soudu stále týž, a to ochrana majetku Stěžovatelky, přičemž zveřejnění fotografie online vedlo $k$ dopadení pachatele. Městský soud tak nepřihlédl $\mathrm{k}$ argumentu ÚOOÚ, že není možné brát spravedlnost do vlastních rukou ani tímto způsobem, když institucionálně $\mathrm{k}$ tomuto slouží policie. ÚOOÚ podal kasační stížnost a NSS rozhodnutí městského soudu zrušil s odkazem na to, že právo Stěžovatelky zpracovávat osobní údaje za účelem ochrany svého majetku je naplněno právě možností jejich zaznamenání a předání policii. Zveřejnění online už toto zákonné oprávnění překračuje. Městský soud v Praze v návaznosti na toto rozhodnutí žalobu zamítl.

Stěžovatelka napadla rozhodnutí NSS z důvodu, že dle jejího názoru jím bylo zasaženo do jejích ústavně garantovaných práv tím, že NSS nedostatečně zhodnotil vztah konfliktních práv.

Ústavní soud zopakoval, že není součástí obecné soudní soustavy, a proto nemůže provádět instanční přezkum rozhodnutí. Konstatoval, že rozhodnutím NSS nebylo zasaženo do Ústavou zaručených práv Stěžovatelky. 
Neshledal totiž, že by názory orgánů veřejné moci v otázce interpretace oprávněnosti zpracování osobních údajů „ve věci stěžovatelky představovaly libovůli nebo jiné vybočení z ústavních mezi““" ${ }^{17}$. Ústavní soud se ztotožnil s názorem NSS, že v případě Stěžovatelky nedošlo k naplnění obou podmínek (nezbytnost zpracování a převážení zájmu na zpracování nad právy subjektu údajů) nezbytných k možnosti aplikace právního titulu zpracování osobních údajů za účelem ochrany práv a právem chráněných zájmů správce. Ochrana majetku totiž měla dle soudu těžiště „zejména po odcizení elektrokola, tedy primárně v př́slušném ř́zení trestním, přestupkovém či občanskoprávním“"18, a Stěžovatelka se proto měla obrátit na orgány veřejné moci.

Ústavní soud tedy stížnost odmítl jako zjevně neopodstatněnou.

\section{JEDNA Z NEJVĚTŠíCH POKUT ZA ZNEUŽÍVÁNí DOMINANTNÍHO POSTAVENÍ UDĚLENÁ SPOLEČNOSTI INTEL BUDE PŘEZKOUMÁNA}

Soud: $\quad$ Soudní dvůr Evropské unie

Věc: $\quad$ C-413/14 P

Datum: $\quad$ 6. 9.2017

Dostupnost: curia.europa.eu

Intel je americkou společností vyrábějící mikroprocesory a jiné polovodičové výrobky. $\mathrm{V}$ daném případě bylo posuzováno chování společnosti na trhu s procesory fungujícími na architektuře x86, která byla v daném období nejrozšířenější pro PC.

V roce 2003 zahájila Evropská komise na základě podnětu konkurenční společnosti AMD řízení. Postupně obvinila společnost Intel z protiprávního jednání vi̊či společnostem vyrábějícím původní koncová zařízení (např. Dell, HP, IBM, Acer) a ze snahy vytěsnit AMD z trhu. Konkrétně se jednalo o podmiňování slev (podmínkou byla nutnost nákupu většiny CPU x86 vy-

\footnotetext{
17 Bod 15 anotovaného rozhodnutí.

18 Bod 19 anotovaného rozhodnutí.
} 
ráběných Intelem) a o tzv. neskrývaná omezení (platby ve prospěch výrobců koncových zařízení za to, že omezí uvádění výrobků AMD na trh). Komise uložila společnosti Intel pokutu ve výši 1,06 miliardy EUR.

SDEU posuzoval, jestli bylo chování společnosti Intel opravdu v rozporu s čl. 102 Smlouvy o fungování Evropské unie a jestli Tribunál (který př́ípad předtím posuzoval) dostatečně zanalyzoval jednotlivé aspekty případu.

Článek 102 SFEU společnosti s dominantním postavením (kterou Intel v dané oblasti byl) zakazuje činnosti, které mohou způsobit vyloučení konkurentů stejně či obdobně výkonných, a posilovat tak své postavení uplatněním jiných prostředků než jsou ty, které spadají do hospodářské soutěže na základě výkonnosti. Již v minulosti bylo judikováno, že vázání kupujících (i na jejich žádost) je zneužitím dominantního postavení bez ohledu na to, zda je taková povinnost stanovena bez dalšího, nebo je vyvážena slevou. ${ }^{19}$ SDEU však uvedl, že je nutno se zabývat situací hlouběji zejména s ohledem na to, že Intel odmítal svou vinu, $\mathrm{k}$ čemuž poskytl relevantní listinné důkazy. Tribunál by tak měl posoudit zejména dosah dominantního postavení společnosti na trhu a dopad dané praktiky. Měl by se rovněž hlouběji zabývat podmínkami a způsoby poskytnutí předmětných slev, dobou jejich trvání, jejich výší a obecně existencí strategie směřující $\mathrm{k}$ vyloučení konkurentů. Přestože se těmito otázkami v původním řízení Komise částečně zabývala, Tribunál je neoprávněně ignoroval a "suše" konstatoval porušení SFEU.

SDEU konstatoval, že Tribunál musí ve světle argumentů společnosti Intel provést takový přezkum, který bude podrobněji posuzovat související skutkové okolnosti a ekonomické údaje, $\mathrm{k}$ čemuž se v minulosti vyjádřil nedostatečně.

SDEU se tak tímto rozhodnutím snaží napravit minulou nedostatečně přesvědčivou argumentaci pro určení výše pokuty. Dosah takového počínání je nutno vnímat globálně, protože například Čína je silně ovlivněna evropskými pravidly při nastavování své antimonopolní legislativy.

19 Bod 137 anotovaného rozhodnutí. 


\section{OBRAT ROZHODOVACÍ PRAXE V OTÁZCE POSKYTOVÁNí INFORMACÍ O PLATECH ZAMĚSTNANCŮ VEŘEJNÉHO SEKTORU \\ Soud: Ústavní soud \\ Věc: $\quad$ IV. ÚS 1378/16 \\ Datum: $\quad$ 17. 10. 2017 \\ Dostupnost: nalus.usoud.cz}

Skupina stěžovatelů (kteří byli vedoucími zaměstnanci statutárního města Zlín) podala ústavní stížnost proti zásahu orgánu veřejné moci spočívajícím v poskytnutí jejich jmenovité identifikace, pracovního zařazení a údajů o platech a odměnách spolku Právo ve veřejném zájmu z.s. na základě žádosti dle zákona č. 106/1999 Sb. Dle názoru stěžovatelů problém podstatně přesahoval jejich vlastní zájmy, protože se týkal cca 1000000 zaměstnanců veřejného sektoru $\mathrm{v}$ ČR, a tak požádali Ústavní soud, aby se věcí zabýval, i když nebyly vyčerpány všechny opravné prostř̌edky.

Ústavní soud se věcí rozhodl zabývat a řešil především otázkou, zda poskytnutím předmětných informací v souladu s § 8b zákona č. 106/1999 Sb. a s na něj navazující ustálenou judikaturou NSS (založenou rozhodnutím ve věci 8 As 55/2012) nedošlo $k$ nepřiměřenému zásahu do Listinou garantovaných práv stěžovatelů.

V př́padu došlo $\mathrm{k}$ aplikaci čl. 10 a 17 LZPS a jim odpovídajících ustanovení mezinárodních lidskoprávních dokumentů, kterými je ČR vázána.

Ústavní soud se ústy amicus curiae nejprve vymezil proti mechanickému přejímání právních pojmů napříč různými předpisy a odmítl interpretaci pojmu „veřejné prostředky“ ve smyslu definice zákona o finanční kontrole, jak ji zavedl NSS. Rovněž odmítl, že by bez dalšího bylo možné tvrdit, že z textu $\S 8 \mathrm{~b}$ je možné vyvodit, že se povinnost poskytnout informace týká i platů a odměn státních zaměstnanců. Za problém také Ústavní soud označil, že NSS ve svém rozhodnutí neprovedl řádně test proporcionality. S odkazem na rozhodovací praxi ESLP a SDEU stanovil, že povinný subjekt může odmítnout poskytnutí požadované informace, pokud žadatel nesplní 
kumulativně všechny čtyři v rozhodnutí uvedené podmínky (účelem vyžádání informace je přispět $\mathrm{k}$ diskusi o věcech veřejného zájmu; informace samotná se týká veřejného zájmu; žadatel o informaci plní úkoly či poslání dozoru veřejnosti či roli tzv. "společenského hlídacího psa"; informace existuje a je dostupná). ${ }^{20}$ Právo na přístup $\mathrm{k}$ informacím je totiž třeba vykládat v souladu s požadavkem přiměřenosti, a proto je třeba hodnotit zvlášt každý případ žádosti o informace. Žádným zákonem totiž není možné abstraktně vyloučit ochranu základních práv a svobod. ${ }^{21}$

Ústavní soud určil, že v uvedeném případě je poskytnutí předmětných údajů zřetelným zásahem do práva stěžovatelů a $\mathrm{z}$ toho důvodu toto poskytnutí pro futuro zapověděl.

Toto dílo lze užít v souladu s licenčními podmínkami Creative Commons BY-SA 4.0 International (http://creativecommons.org/licenses/by-sa/4.0/legalcode).

20 Bod 125 anotovaného rozhodnutí.

${ }^{21}$ Bod 135 anotovaného rozhodnutí. 